\title{
PERAN LINGKUNGAN KAMPUS DALAM MEMODERASI PENGARUH MATA KULIAH KEWIRAUSAHAAN TERHADAP MINAT WIRAUSAHA
}

\author{
Tanti Prita Hapsari, Universitas AMIKOM Yogyakarta \\ tantiprita@amikom.ac.id
}

\begin{abstract}
ABSTRAK
Penelitian ini bertujuan untuk menguji 1) pengaruh mata kuliah kewirausahaan terhadap minat mahasiswa berwirausaha dan 2) peran lingkungan kampus dalam memoderasi pengaruh mata kuliah kewirausahaan terhadap minat mahasiswa berwirausaha. Alasan penelitian ini penting dilakukan karena penelitian tentang pengaruh mata kuliah kewirausahaan terhadap minat mahasiswa berwirausaha di kalangan Universitas Amikom Yogyakarta belum pernah dilakukan sebelumnya. Mata kuliah kewirausahaan merupakan salah satu mata kuliah wajib Universitas yang ditawarkan di Universitas Amikom dengan didukung oleh lingkungan kampus yang berbasis kewirausahaan. Responden yang dipilih dan digunakan dalam penelitian ini adalah mahasiswa Universitas Amikom Yogyakarta. Terdapat 115 responden dari 150 kuesioner yang bisa dijadikan sampel. Analisis data dilakukan dengan regresi sederhana dan moderated regression analysis. Hasil penelitian menunjukkan bahwa 1) terdapat pengaruh yang positif dan signifikan dari mata kuliah kewirausahaan terhadap minat mahasiswa berwirausaha dan 2) lingkungan kampus tidak memoderasi pengaruh mata kuliah kewirausahaan terhadap minat mahasiswa berwirausaha.
\end{abstract}

Kata Kunci: Pendidikan Kewirausahaan, Minat Wirausaha Mahasiswa, Lingkungan Kampus.

\section{ABSTRACT}

The purpose of this research was to determine (1) the influences of entrepreneurship course towards the students' interest in entrepreneurship (2) the influences of university's environment in moderating the correlation between entrepreneurship courses towards the students' interest in entrepreneurship. This research is very important because it has never been done before and entrepreneurship course is one of compulsory course in Amikom University of Yogyakarta which is supported by an entrepreneurial-based university's environment. The population of this research were the students of Amikom University of Yogyakarta and 115 respondents of 150 questionnaires were used as sample. Simple regression analysis and moderated regression analysis were used in this research. The researcher found that (1) there was positive and significant effect of entrepreneurship course toward the students' interest in entrepreneurship (2) university's environment did not 
moderate the correlation between entrepreneurship courses toward the students' interest in entrepreneurship.

Keywords: Entrepreneurship Course, Students' Interest, University's Environment.

\section{PENDAHULUAN}

Pendidikan Tinggi atau Universitas menjadi mesin yang membentuk lulusan menjadi pribadi yang cerdas, kreatif dan mandiri sehingga mereka memiliki softskill dan hardskill yang berkualitas. Berbagai fakultas, jurusan dan atau program studi yang ditawarkan seharusnya disesuaikan dengan kebutuhan pasar tenaga kerja yang ada. Pendidikan Tinggi juga harus dapat membentuk pribadi mahasiswa yang berani mengambil resiko dan memiliki jiwa entrepreneurship. Hal ini disebabkan dengan semakin tingginya persaingan dan pertambahan jumlah penduduk maka lapangan pekerjaan juga menyempit. Menjadi wirausahawan merupakan salah satu pilihan untuk menghadapi ketimpangan tersebut. Oleh karena itu sebuah pendidikan tinggi harus berupaya menumbuhkan minat mahasiswanya untuk berwirausaha, salah satunya dengan memberikan mata kuliah kewirausahaan. Tujuan dari mata kuliah kewirausahaan ini adalah untuk memberikan landasan teoritis mengenai konsep kewirausahaan.

Berdasarkan Pedoman Program Mahasiswa Wirausaha (2015), pada tahun 2009 Pemerintah melalui Direktorat Jenderal Pendidikan Tinggi Kementerian Pendidikan dan Kebudayaan telah meluncurkan Program Mahasiswa Wirausaha (PMW) untuk dilaksanakan dan dikembangkan oleh perguruan tinggi. Program tersebut dilaksanakan di seluruh Perguruan Tinggi Negeri (PTN) dan di beberapa Perguruan Tinggi Swasta (PTS). Program ini bertujuan untuk memberikan bekal pengetahuan, ketrampilan dan sikap atau jiwa wirausaha (entrepreneurship) berbasis IPTEK kepada para mahasiswa agar dapat mengubah pola pikir (mindset) dari pencari kerja (job seeker) menjadi pencipta lapangan pekerjaan (job creator) serta menjadi calon/pengusaha yang tangguh dan sukses menghadapi persaingan global. Disamping itu juga untuk mendorong kelembagaan atau unit kewirausahaan di perguruan tinggi agar dapat mendukung pengembangan program-program kewirausahaan. Sebagai hasil akhir, diharapkan terjadinya penurunan angka pengangguran lulusan pendidikan tinggi.

Terdapat beberapa universitas di Indonesia yang sudah memiliki jurusan kewirausahaan diantaranya yaitu Prasetiya Mulya Business School, Universitas Ciputra, Universitas Bina Nusantara, Surya University, Universitas Amikom dan Institut Teknologi Bandung. Namun meskipun begitu nyatanya minat wirausaha mahasiswa masih rendah, mahasiswa setelah tamat sarjana justru lebih memilih bekerja di perusahaan dan lebih memilih pekerjaan yang sesuai dengan pendidikannya. Kondisi tersebut menyebabkan tingginya tingkat pengangguran dari kalangan sarjana. Berdasarkan data Badan Pusat Statistik (BPS), tingkat pengangguran terbuka pada Februari 2017 sebesar 5,33\%. Meskipun jumlah pengangguran tersebut menurun dibanding bulan Februari 2016 yang mencapai 5,5\% namun dapat dikatakan cukup tinggi. Badan Pusat 
Statistik (BPS) mengungkapkan bahwa angka pengangguran dari tingkat pendidikan di level Universitas akan terus ada setiap tahunnya.

Penelitian tentang pengaruh mata kuliah kewirausahaan terhadap minat berwirausaha sebelumnya pernah dilakukan oleh Ramadhani dan Nurnida (2017) dengan hasil bahwa mata kuliah kewirausahaan berpengaruh terhadap minat berwirausaha mahasiswa. Materi yang disampaikan memiliki peran besar bagi mahasiswa, karena dengan diberikannnya materi-materi yang baru maka wawasan mahasiswa akan bertambah. Selain itu, cara penyampaian materi yang baik akan menimbulkan pemahaman yang mendalam bagi mahasiswa sehingga mahasiswa dapat menguasai pembelajaran yang telah diberikan. Menurut Wiyadi dan Rochmania (2016), mata kuliah kewirausahaan memberikan pengaruh terhadap minat mahasiswa berwirausaha. Semakin banyak mahasiswa memperoleh pemahaman materi tentang kewirausahaan tentu akan meningkatkan minat mahasiswa dalam berwirausaha. Penelitian tentang pengaruh mata kuliah kewirausahaan terhadap minat berwirausaha dengan menambahkan variabel moderasi yaitu lingkungan kampus belum pernah dilakukan sebelumnya, sementara diketahui bahwa lingkungan kampus dapat mempengaruhi minat mahasiswa untuk berwirausaha. Lingkungan kampus merupakan faktor eksternal yang layak dipertimbangkan ketika menguji pengaruh mata kuliah kewirausahaan terhadap minat berwirausaha.

Lingkungan kampus dalam penelitian ini menjadi variabel moderasi karena lingkungan kampus dapat memperkuat atau memperlemah pengaruh mata kuliah kewirausahaan terhadap minat mahasiswa berwirausaha. Penelitian yang terkait dengan pengaruh lingkungan kampus terhadap minat berwirausaha mahasiswa menunjukkan bahwa di dalam lingkungan kampus mahasiswa dapat berinteraksi dengan dosen, teman kuliah serta orang-orang yang ditemui di saat mahasiswa melaksanakan on the job training. Mahasiswa mendapatkan motivasi yang tinggi di saat berinteraksi dengan dosen baik dalam kegiatan kuliah secara klasikal, maupun dalam pertemuan tidak formal. Dosen yang umumnya memberikan motivasi kepada mahasiswa untuk berwirausaha adalah dosen kewirausahaan, karena salah satu tujuan dari mata kuliah ini adalah menumbuhkan minat mahasiswa untuk berwirausaha. Di samping dosen, teman kuliah pun memberikan dorongan yang tinggi kepada teman mahasiswa untuk berwirausaha, karena ternyata di lingkungan tempat kuliah terdapat banyak mahasiswa yang sudah memulai berwirausaha. Hal ini pun terjadi di saat mahasiswa melaksanakan on the job training, juga mendapatkan motivasi berwirausaha. Dapat dijelaskan bahwa baik dosen, teman kuliah di kampus, maupun orang-orang yang berinteraksi sosial dalam kegiatan on the job training, pada umumnya memberikan dorongan yang maksimal kepada mahasiswa untuk memulai berwirausaha (Syarifuddin dan Iskandar, 2016).

Universitas Amikom merupakan Universitas yang berbasis kewirausahaan dan telah diakui oleh UNESCO. Terdapat beberapa destinasi kreatif berbasis information technology (IT) yang dimiliki oleh Universitas Amikom dan diyakini akan mampu mengembangkan kemampuan mahasiswanya di bidang kewirausahaan dan dapat menjamin keberlangsungan hidup Universitas Amikom. Disamping itu, dalam kurikulum di Universitas Amikom juga sudah terdapat mata kuliah kewirausahaan dengan harapan mahasiswa dapat lebih terpacu untuk menjadi wirausahawan. 


\section{Pendidikan (Mata Kuliah) Kewirausahaan}

Kewirausahaan menurut Intruksi Presiden RI No.4 Tahun 1995 adalah semangat, sikap dan perilaku dan kemampuan seseorang dalam menangani usaha dan atau kegiatan yang mengarah pada upaya mencari, menciptakan, menerapkan cara kerja, teknologi, dan produk baru dengan meningkatkan efisiensi dalam rangka memberikan pelayanan yang lebih baik dan atau memperoleh keuntungan yang lebih besar. Sementara wirausahawan (entrepreneur) adalah seseorang yang memutuskan untuk memulai suatu bisnis, sebagai pewaralaba (franchisor) menjadi terwaralaba (franchisee), memperluas sebuah perusahaan, membeli perusahaan yang sudah ada, atau barangkali meminjam uang untuk memproduksi suatu produk baru atau menawarkan suatu jasa baru, serta merupakan manajer dan penyandang resiko (Saiman, 2014).

Menurut Kodrat dan Christina (2015), entrepreneurship belum menjadi mature subject meskipun telah terjadi ledakan jumlah pendidikan entrepreneurship. Kurangnya data dan rendahnya penelitian entrepreneurship menjadikan pendidikan entrepreneurship belum efektif. Pendidikan entrepreneurship adalah konten, metode dan kegiatan yang mendukung terciptanya pengetahuan, kompetensi dan pengalaman yang memungkinkan peserta didik untuk memulai dan berpartisipasi dalam proses menciptakan nilai wirausaha (Lackeus, 2015). Pendidikan kewirausahaan di perguruan tinggi berkaitan dengan membangun karakter wirausaha, pola pikir wirausaha, dan perilaku wirausaha yang selalu kreatif dan inovatif, menciptakan nilai tambah atau nilai-nilai baik (values), memanfaatkan peluang dan berani mengambil resiko (Susilaningsih, 2015).

Pendidikan kewirausahaan berusaha untuk mendorong seseorang, terutama kaum muda untuk bertanggung jawab sebagaimana individu yang menjadi pengusaha atau entrepreneurial thinkers yang berkontribusi terhadap perkembangan ekonomi dan masyarakat secara berkelanjutan (Raposo dan Paco, 2011). Pendidikan kewirausahaan berkaitan dengan konten, metode dan aktivitas yang mendukung penciptaan dan pengembangan pengetahuan, kompetensi dan pengalaman yang diinginkan dan layak untuk siswa memulai dan berpartisipasi dalam proses penciptaan nilai wirausaha (Moberg et al, 2014).

Pendidikan kewirausahaan masuk dalam kurikulum pembelajaran yang mewajibkan mahasiswa menempuh mata kuliah kewirausahaan. Hal ini menunjukkan bahwa kewirausahaan sebagai mata kuliah yang penting untuk dipelajari. Pendidikan atau mata kuliah kewirausahaan meliputi penanaman jiwa entrepreneurship, motivasi dan mindset wirausaha, menilai dan memilih peluang usaha, mengelola usaha terkait dengan keuangan dan sumber daya manusia sampai dengan membuat rencana bisnis (business plan). Mata kuliah kewirausahaan merupakan pelajaran yang membentuk karakter wirausaha atau minimal menambah pengetahuan mahasiswa mengenai seluk-beluk bisnis baik dari sisi soft skill maupun hard skill sehingga mahasiswa mampu memanfaatkan peluang-peluang yang ada di sekitarnya dalam menciptakan usaha sendiri setelah lulus maupun saat masih kuliah (Rahmi, 2015). Dahulu, 
kewirausahaan dianggap hanya dapat dilakukan melalui pengalaman langsung di lapangan dan merupakan bakat yang dibawa sejak lahir (entrepreneurship are born not made) sehingga kewirausahaan tidak dapat dipelajari dan diajarkan. Sekarang, kewirausahaan bukan hanya urusan lapangan, tetapi merupakan disiplin ilmu yang dapat dipelajari dan diajarkan. Entrepreneurshipare not only born but also made artinya kewirausahaan tidak hanya bakat bawaan sejak lahir atau urusan pengalaman lapangan, tetapi juga dapat dipelajari dan diajarkan. Seseorang yang memiliki bakat kewirausahaan dapat mengembangkan bakatnya melalui pendidikan (Suryana, 2003).

\section{Lingkungan Kampus}

Perilaku kewirausahaan dipengaruhi oleh faktor internal dan eksternal. Faktor-faktor itu adalah hak kepemilikan (property right, PR), kemampuan/ kompetensi (competency/ ability, C), dan intensif (incentive), sedangkan faktor eksternalnya meliputi lingkungan (environment, E) (Suryana, 2003). Faktor internal adalah faktor yang timbul karena pengaruh dari dalam diri individu itu sendiri seperti kebutuhan akan pendapatan, harga diri, perasaan senang, dan lain-lain. Faktor eksternal adalah faktor yang mempengaruhi individu karena pengaruh dari luar dirinya sendiri yang meliputi lingkungan keluarga, lingkungan masyarakat, lingkungan internasional, perubahan teknologi, kondisi ekonomi, budaya dan sosial (Ginting dan Yuliawan, 2015).

Pendapat lain dikemukakan oleh Stewart et al (1998) yaitu tumbuhnya minat berwirausaha dipengaruhi oleh berbagai faktor yang melibatkan faktor internal, faktor eksternal dan faktor kontekstual. Faktor internal berasal dari dalam diri wirausahawan dapat berupa sifat-sifat, personal, sikap, kemauan dan kemampuan individu yang dapat memberi kekuatan individu untuk berwirausaha. Sedangkan faktor eksternal berasal dari luar diri pelaku entrepreneur yang dapat berupa unsur dari lingkungan sekitar seperti lingkungan keluarga, lingkungan dunia usaha, lingkungan fisik, lingkungan sosial ekonomi dan lain-lain. Lingkungan kampus merupakan salah satu faktor yang berasal dari luar diri seseorang. Lingkungan kampus adalah lingkungan dimana mahasiswa menjalani proses belajar dan melakukan aktivitas (Naibaho dkk, 2010). Lingkungan kampus meliputi bentuk dukungan dari universitas bagi mahasiswa untuk berwirausaha yang terdiri dari penyediaan sarana dan prasarana bagi praktek kewirausahaan, kegiatan pelatihan dan seminar kewirausahaan serta penyediaan wadah bagi mahasiswa untuk praktek kewirausahaan (misalnya entrepreneur days).

\section{Minat Wirausaha}

Menurut Slameto dalam Nurikasari (2016) minat adalah rasa lebih suka dan rasa ketertarikan pada suatu hal atau aktivitas, tanpa ada yang menyuruh. Minat pada dasarnya adalah penerimaan akan suatu hubungan antara diri sendiri dengan sesuatu di luar diri. Semakin kuat atau dekat hubungan tersebut, semakin besar minatnya. Minat berwirausaha dapat terus dikembangkan menjadi usaha nyata sebagai aplikasi dari jiwa kewirausahaan yang dimiliki (Kadarsih dkk, 2013).

Minat seseorang terhadap suatu obyek diawali dari perhatian seseorang terhadap obyek tersebut. Minat tidak dibawa sejak lahir, melainkan tumbuh dan 
berkembang sesuai dengan faktor-faktor yang mempengaruhinya. Minat dapat berubah-ubah tergantung dari faktor-faktor yang mempengaruhinya di antaranya adalah faktor lingkungan (Ginting dan Yuliawan, 2015). Budiati, Yani, dan Universari dalam Rosmiati, Junias dan Munawar (2015) menyatakan bahwa minat mahasiswa menjadi wirausaha dibagi dalam empat kelompok yaitu: 1) Minat untuk memulai wirausaha dalam jangka waktu dekat 2) Minat untuk memulai wirausaha dua tahun mendatang 3) Minat untuk memulai wirausaha untuk jangka panjang, dan 4) Tidak memiliki minat berwirausaha. Sementara itu, minat berwirausaha diukur dengan adanya minat mahasiswa untuk menjadi wirausaha sehingga mereka dapat menjadi lebih mandiri, membuka lapangan pekerjaan, memiliki kehidupan ekonomi yang lebih baik dan memilih karir menjadi seorang wirausaha (entrepreneur).

\section{Hubungan Mata Kuliah Kewirausahaan dengan Minat Wirausaha}

Penelitian tentang mata kuliah kewirausahaan pernah dilakukan oleh Wiyadi dan Rochmania (2016) yang meneliti tentang Pengaruh Kuliah Kewirausahaan dan Motivasi Diri Terhadap Minat Berwirausaha Mahasiswa UNHASY Jombang dengan hasil bahwa mata kuliah kewirausahaan memberikan pengaruh terhadap minat mahasiswa berwirausaha. Hal ini menunjukkan bahwa semakin banyak mahasiswa memperoleh pemahaman materi tentang kewirausahaan tentu akan meningkatkan minat mahasiswa berwirausaha. Lestari dan Wijaya (2012) juga menemukan bahwa pendidikan kewirausahaan berpengaruh secara signifikan terhadap minat berwirausaha dimana minat berwirausaha mahasiswa juga diperkuat oleh faktor demografis seperti gender, pengalaman kerja dan pekerjaan orang tua.

Pengetahuan yang didapat selama kuliah merupakan modal dasar yang digunakan untuk berwirausaha, juga ketrampilan yang didapat selama perkuliahan terutama mata kuliah praktek. Hal ini menunjukkan bahwa mahasiswa mengakui selain mendapatkan ilmu dari mata kuliah kewirausahaan, proses pembelajaran ini melalui penanaman tentang nila-nilai, pemahaman, jiwa, sikap dan perilaku juga menumbuhkan pemikiran dan karakteristik wirausaha dan hal ini mendukung minat mereka menjadi pengusaha (Hermina, Novieyana dan Zain, 2011). Pendidikan juga mempengaruhi minat wirausaha seseorang. Universitas (melalui pendidikan) memiliki peran untuk memotivasi siswa dalam berwirausaha. Dengan motivasi tersebut akan memungkinkan sikap siswa tertarik memilih karir untuk bisnis/ kewirausahaan (Yohnson dalam Hajrah, Siswoyo dan Rahayu, 2016).

\section{Lingkungan Kampus Memoderasi Pengaruh Mata Kuliah Kewirausahaan Terhadap Minat Wirausaha}

Faktor yang mendorong minat berwirausaha adalah lingkungan yang banyak dijumpai kegiatan-kegiatan berwirausaha, pelatihan kewirausahaan, teman pergaulan, lingkungan family, sahabat yang dapat diajak berdiskusi tentang ide wirausaha, pendidikan formal, pengalaman bisnis kecil-kecilan (Syarifuddin dan Iskandar, 2016). Pada umumnya pengaruh lingkungan sekitar (fisik maupun sosial) bersifat pasif, dalam arti bahwa lingkungan tidak memberikan suatu paksaan terhadap individu. Lingkungan hanya memberikan kesempatan-kesempatan atau peluang. Bagaimana individu mengambil 
kesempatan atau peluang tersebut tergantung pada yang bersangkutan. Tidak demikian halnya dengan pendidikan, terutama yang langsung berhubungan dengan wirausaha. Pendidikan dijalankan dengan penuh kesadaran, mempunyai tujuan, target, dan sasaran tertentu serta diberikan secara sistematis untuk mengembangkan potensi-potensi yang ada (Wibowo, 2011).

Menurut Cooper dan Artz dalam Koranti (2013) pengaruh lingkungan sebagai faktor penentu kesuksesan berwirausaha. Kondisi lingkungan merupakan salah satu faktor utama yang dapat memperkuat atau memperlemah minat berwirausaha (Sadeghi et al, 2013). Lingkungan menjadi faktor penentu tumbuhnya minat mahasiswa untuk berwirausaha. Semakin sering mahasiswa berada dalam lingkungan yang memberikan motivasi berwirausaha, maka semakin tinggi pula minat mahasiswa untuk berwirausaha yang dimungkinkan dapat memulai berwirausaha (Syarifuddin dan Iskandar, 2016).

Berdasarkan pada uraian diatas, maka peneliti mengajukan hipotesis penelitian sebagai berikut: (1) Mata kuliah kewirausahaan berpengaruh secara positif dan signifikan terhadap minat wirausaha, (2) Lingkungan kampus memoderasi pengaruh mata kuliah kewirausahaan terhadap minat wirausaha

Berdasarkan pemaparan tersebut diatas maka penelitian ini penting dilakukan untuk mengetahui pengaruh mata kuliah kewirausahaan terhadap minat wirausaha di kalangan mahasiswa Universitas Amikom yang dimoderasi oleh lingkungan kampus. Penelitian tentang pengaruh mata kuliah kewirausahaan terhadap minat mahasiswa berwirausaha di kalangan Universitas Amikom belum pernah dilakukan sebelumnya. Mahasiswa Universitas Amikom yang sudah mengambil mata kuliah kewirausahaan akan memiliki bekal teoritis tentang kewirausahaan sehingga akan memiliki minat berwirausaha. Tumbuhnya minat tersebut seharusnya juga diperkuat dengan lingkungan kampus yang berbasis kewirausahaan, semakin tinggi interaksi mahasiswa dengan lingkungan Universitas seharusnya akan semakin tinggi pula minat untuk berwirausaha.

\section{METODE PENELITIAN}

Penelitian ini dilakukan untuk memahami fenomena (need to know) yaitu untuk menggambarkan fakta, membuktikan, mengembangkan dan menemukan pengetahuan. Jenis penelitian ini merupakan penelitian kausal komparatif yaitu bertujuan untuk menyelidiki kemungkinan sebab akibat terjadinya suatu fenomena (Suryana, 2010).Sementara itu, berdasarkan jenis tujuannya penelitian ini merupakan penelitian explanatory (penjelasan). Menurut Jogiyanto (2005), penelitian explanatory (penjelasan) merupakan riset yang mencoba menjelaskan fenomena yang ada.

Penelitian ini menggunakan metode pengumpulan data yaitu observasi, kuesioner dan beberapa literatur yang terkait. Sementara itu, populasi dalam penelitian ini adalah mahasiswa/ mahasiswi Universitas Amikom Yogyakarta. Teknik sampling yang digunakan adalah non probability dengan teknik purposive sampling. Teknik purposive sampling adalah teknik penentuan sampel dengan pertimbangan tertentu (Sugiyono, 2016). Teknik purposive sampling atau sampel bersyarat digunakan berdasarkan pada kriteria yaitu mahasiswa/ mahasiswi yang sudah mengambil mata kuliah kewirausahaan 
sehingga mahasiswa Amikom yang digunakan adalah angkatan tahun 2016, tahun akademik 2017/2018. Alasan yang mendasari pengambilan sampel ini karena mahasiswa yang sudah mengambil mata kuliah kewirausahaan lebih mewakili sehingga penilaian mereka akan lebih objektif dibanding mahasiswa yang belum atau tidak mengikuti mata kuliah kewirausahaan.

\section{Tabel 1. Indikator Variabel}

\section{Mata Kuliah Kewirausahaan}

Pemahaman mahasiswa terhadap maksud dan tujuan mata kuliah kewirausahaan.

Pemahaman mahasiswa terhadap isi silabus dan RPS sebagai acuan belajar.

Isi silabus sudah mencakup tujuan mata kuliah kewirausahaan yang akan dicapai.

Kesesuaian materi yang diberikan dengan isi silabus.

Kesesuaian metode pembelajaran yang digunakan dengan materi yang akan disampaikan.

Pemahaman terhadap konsep kewirausahaan

Antusiasme mengikuti mata kuliah kewirausahaan.

Mata kuliah kewirausahaan merupakan mata kuliah yang menyenangkan.

Mata kuliah kewirausahaan menjadi modal penting untuk memulai berwirausaha.

Minat Wirausaha

Mahasiswa berminat menjadi wirausaha sehingga menjadi lebih mandiri.

Mahasiswa berminat menjadi wirausaha karena dapat membantu orang lain (menciptakan lapangan kerja).

Mahasiswa lebih memilih berkarier sebagai seorang wirausaha.

Mahasiswa senang bilamana menjadi wirausaha.

Mahasiswa tertarik untuk memulai bisnis.

Mahasiswa menganggap akan memperoleh penghasilan yang lebih baik dengan berwirausaha.

\section{Lingkungan Kampus}

Universitas mendukung mahasiswa untuk berwirausaha.

Universitas akan membantu mahasiswa dalam berwirausaha.

Universitas menyediakan sarana dan prasarana untuk praktek kewirausahaan.

Universitas sering mengadakan seminar kewirausahaan yang ditujukan untuk mahasiswa.

Universitas sering mengadakan pelatihan kewirausahaan yang mendorong mahasiswa untuk berwirausaha.

Universitas menyediakan wadah untuk mahasiswa praktik kewirausahaan (misal entrepreneur days).

Saya pernah melakukan praktek wirausaha di dalam lingkungan kampus.

Teknik pengambilan sampel dilakukan dengan non probability yaitu teknik pengambilan sampel yang tidak memberikan peluang atau kesempatan sama bagi setiap unsur atau anggota populasi untuk dipilih menjadi sampel. Menurut Hair et al., (2006) jumlah sampel yang harus dipenuhi rasio minimal 5:1, yaitu antara 15 sampai dengan 20 kali jumlah variabel independen. Penelitian ini mempunyai satu variabel independen sehingga harus memenuhi target minimal 15 sampai dengan 20. Jumlah sampel yang digunakan dalam 
penelitian ini sebanyak 150. Indikator yang digunakan untuk variabel penelitian ini disajikan pada Tabel 1 .

Model dalam penelitian ini dapat dilihat di gambar 1 sebagai berikut:

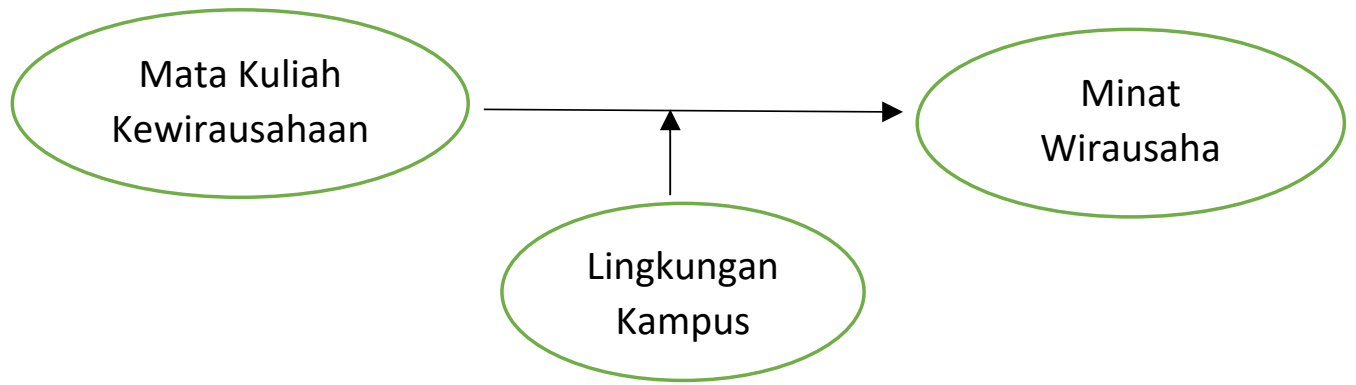

Gambar 1. Model Penelitian

Sumber: Dimodifikasi dari Hajrah, Siswoyo dan Rahayu (2016)

Adapun metode analisis data yang digunakan adalah analisis regresi sederhana dan moderated regression analysis. Analisis regresi sederhana digunakan untuk menguji pengaruh variabel mata kuliah kewirausahaan (X) terhadap minat wirausaha (Y). Sementara, moderated regression analysis merupakan bentuk regresi secara hierarkis untuk menentukan hubungan antara dua variabel yang dipengaruhi oleh variabel ketiga atau moderasi (Hair et al., 2006).

Pengujian dilakukan dengan mengacu pada model yang dikembangkan oleh Baron dan Kenny (1986) berikut ini:

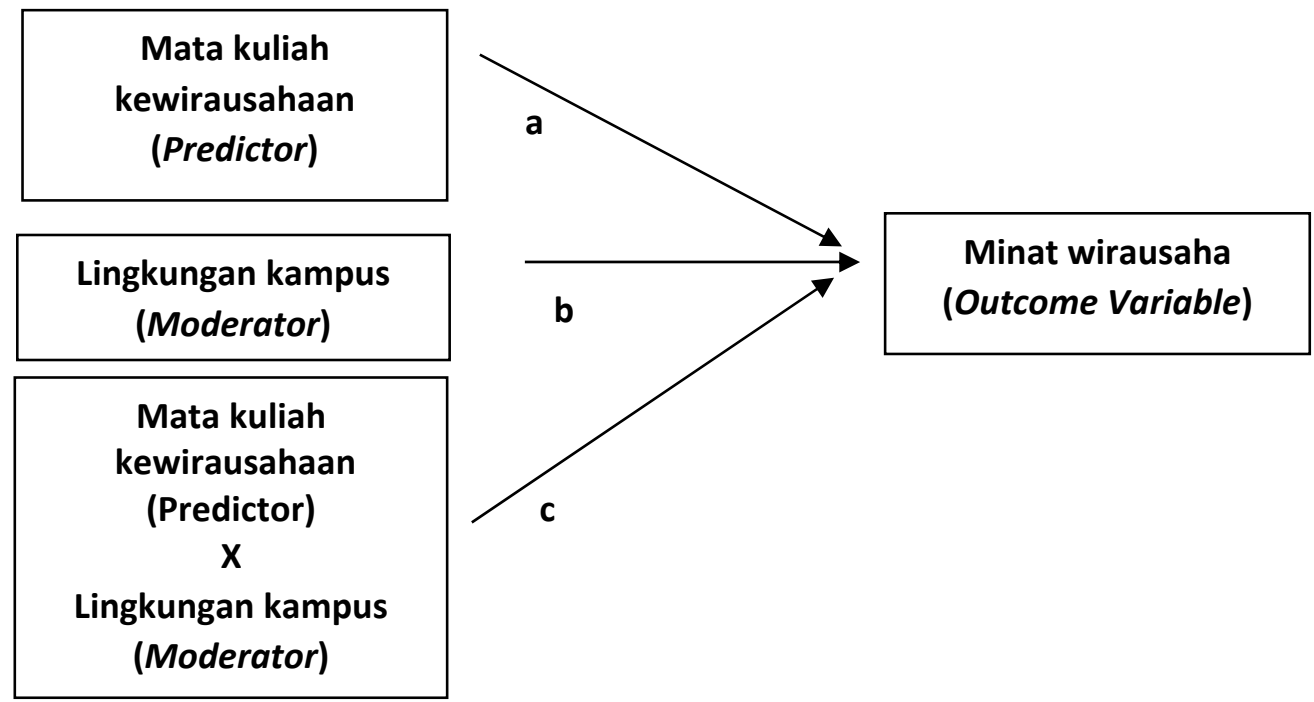

Gambar 2. Moderator Model

Sumber: Baron dan Kenny, 1986

Gambar tersebut menunjukkan bahwa hipotesis yang menyatakan suatu variabel berperan sebagai moderator akan didukung jika interaksi (path $c$ ) adalah signifikan. Langkah-langkah yang harus dilakukan untuk menguji variabel lingkungan kampus sebagai variabel moderator dalam penelitian adalah 1) Analisis regresi variabel mata kuliah kewirausahaan (MK) dengan variabel minat wirausaha (MW), $\mathrm{L}=\mathrm{a}+\mathrm{b}_{2} \mathrm{MK}+\mathrm{e}, 2$ ) Analisis regresi variabel 
mata kuliah kewirausahaan (MK) dengan variabellingkungan kampus(LK) untuk memprediksi variabel minat wirausaha (MW), $\mathrm{L}=\mathrm{a}+\mathrm{b}_{1} \mathrm{MK}+\mathrm{b}_{2} \mathrm{LK}+$ e, 3) Analisis regresi variabel mata kuliah kewirausahaan (MK) dengan variabel lingkungan kampus(LK) dan interaksi mata kuliah kewirausahaan (MK) dikalikan dengan variabellingkungan kampus(LK) untuk memprediksi variabel minat wirausaha (MW), $\mathrm{L}=\mathrm{a}+\mathrm{b}_{1} \mathrm{MK}+\mathrm{b}_{2} \mathrm{LK}+\mathrm{b}_{3} \mathrm{MK} . \mathrm{LK}+\mathrm{e}$.

Berdasarkan pada langkah-langkah tersebut diatas maka lingkungan kampus(LK) memoderasi apabila memenuhi kriteria 1) pengaruh pemoderasi penuh (fully moderated) yaitu jika interaksi antara variabel mata kuliah kewirausahaan (MK) dan lingkungan kampus(LK) (path $c$ ) signifikan yaitu $\mathrm{b}_{3}$ harus signifikan pada $5 \%$ atau $10 \%$, sementara $b_{1}$ danb 2 tidak signifikan pada $5 \%$ atau $10 \%, 2$ ) Pengaruh pemoderasi parsial (partially moderated) yaitu jika $\mathrm{b}_{2}$ dan $\mathrm{b}_{3}$ signifikan pada $5 \%$ atau $10 \%$, b dan $\mathrm{b}_{3}$ signifikan pada $5 \%$ atau $10 \%$, $b_{1}$ dan $b_{2}$ signifikan pada $5 \%$ atau $10 \%$.

Analisis data dilakukan dengan regresi menggunakan bantuan softwareSPSS 16,0 for windows. Analisis moderasi bertujuan untuk menguji pengaruh lingkungan kampus dalam memoderasi pengaruh mata kuliah kewirausahaan $(\mathrm{X})$ terhadap minat wirausaha $(\mathrm{Y})$.

\section{HASIL PENELITIAN DAN PEMBAHASAN}

Berdasarkan hasil uji regresi sederhana danmoderated regression analysisdapat diketahui bahwa satu hipotesis penelitian ini didukung. Berikut ini pembahasan hasil pengujian hipotesis:

\section{Mata Kuliah Kewirausahaan Berpengaruh Secara Positif dan Signifikan Terhadap Minat Wirausaha} berikut:

Berdasarkan hasil pengujian regresi sederhana didapatkan hasil sebagai

\section{Tabel 2. Hasil Regresi Sederhana}

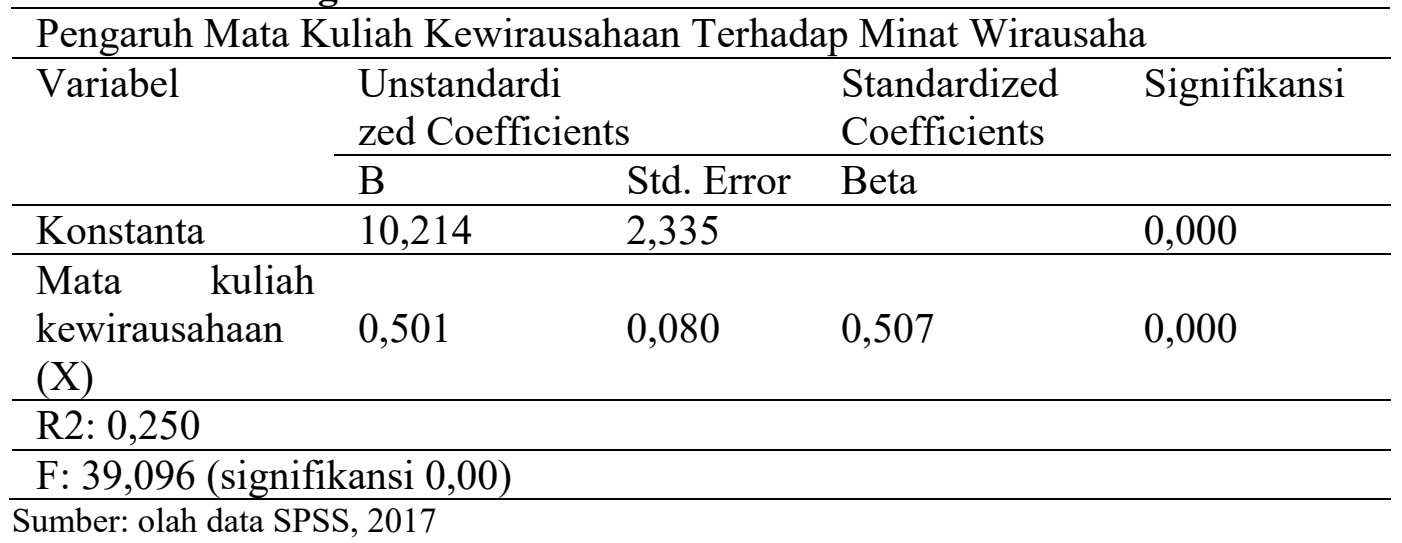

Berdasarkan tabel tersebut dapat diketahui bahwa variabel mata kuliah kewirausahaan $(\mathrm{X})$ berpengaruh secara positif dan signifikan terhadap variabel minat wirausaha $(\mathrm{Y})$ karena memiliki nilai signifikansi lebih kecil dari 0,05. Sementara nilai $\mathrm{R}^{2}$ adalah 0,250 yang mempunyai arti bahwa $25 \%$ variasi 
variabel minat wirausaha $(\mathrm{Y})$ dapat dijelaskan oleh variasi variabel mata kuliah kewirausahaan $(\mathrm{X})$ sedangkan sisanya $(75 \%)$ dijelaskan oleh variabel lain yang tidak masuk dalam model ini. Dengan demikian hipotesis yang menyatakan terdapat pengaruh mata kuliah kewirausahaan terhadap minat wirausaha terbukti. Persamaan yang dihasilkan adalah $\mathrm{Y}=10,214+0,501 \mathrm{X}$.

Hasil penelitian ini konsisten dengan penelitian sebelumnya yang dilakukan oleh Wiyadi dan Rochmania (2016) yaitu mata kuliah kewirausahaan memberikan pengaruh terhadap minat berwirausaha, semakin banyak mahasiswa mendapatkan pemahaman materi tentang kewirausahaan akan semakin meningkatkan minat wirausaha. Disamping itu, hasil penelitian ini juga mendukung penelitian Hermina, Novieyana dan Zain (2011) yang menunjukkan bahwa pengetahuan yang didapat selama kuliah digunakan sebagai modal dasar untuk berwirausaha. Hal ini menunjukkan bahwa dengan menempuh mata kuliah kewirausahaan maka akan menumbuhkan minat mahasiswa untuk berwirausaha.

Mata kuliah kewirausahaan berpengaruh terhadap minat wirausaha karena dengan mengikuti mata kuliah tersebut maka mahasiswa akan memiliki ilmu kewirausahaan yang dapat digunakan sebagai bekal untuk menjadi wirausaha. Mata kuliah kewirausahaan mencakup berbagai macam konsep dasar kewirausahaan, sikap dan perilaku wirausaha, proses kewirausahaan hingga mempelajari tentang start up menjadi wirausaha sehingga dengan begitu akan menumbuhkan minat mahasiswa untuk berwirausaha.

\section{Lingkungan Kampus Tidak Memoderasi Pengaruh Mata Kuliah Kewirausahaan Terhadap Minat Wirausaha}

Berdasarkan hasil pengujian moderated regression analysis seperti disajikan pada Tabel 3. diketahui bahwa uji t statistik dari ketiga variabel yang dimasukkan dalam regresi hanya variabel mata kuliah kewirausahaan (X) yang memiliki pengaruh terhadap minat wirausaha (Y). Hal ini dapat dilihat dari nilai signifikansinya yaitu sebesar 0,014 dengan nilai koefisien parameter sebesar 1,277. Variabel lingkungan kampus tidak berpengaruh terhadap variabel minat wirausaha (Y) karena memiliki nilai signifikansi sebesar 0,086 yaitu lebih besar dari 0,05 dan memiliki nilai koefisien parameter sebesar 0,957. Variabel moderat yang merupakan interaksi antara mata kuliah kewirausahaan dan lingkungan kampus ternyata tidak signifikan karena memiliki nilai signifikansi sebesar 0,108 dan nilai koefisien parameter sebesar -0,032. Sehingga dapat disimpulkan bahwa lingkungan kampus tidak memoderasi pengaruh mata kuliah kewirausahaan terhadap minat wirausaha. Dengan demikian hipotesis yang menyatakan lingkungan kampus tidak memoderasi pengaruh mata kuliah kewirausahaan terhadap minat wirausaha terbukti.

Uji statistik F menghasilkan nilai hitung sebesar 14,321 dengan tingkat signifikansi 0,00 . Karena nilai signifikansi jauh lebih kecil dari 0,05 maka model regresi dapat digunakan untuk memprediksi minat wirausaha atau dapat dikatakan bahwa variabel mata kuliah kewirausahaan, variabel lingkungan kampus dan variabel moderat berpengaruh secara positif dan signifikan terhadap minat wirausaha secara bersama-sama. Selanjutnya, nilai $\mathrm{R}^{2} \mathrm{yang}$ dihasilkan sebesar 0,260 (26\%) yang artinya variasi variabel minat wirausaha 
(Y) dapat dijelaskan oleh variasi variabel mata kuliah kewirausahaan, variabel lingkungan kampus dan variabel moderat (mata kuliah kewirausahaan $\mathrm{x}$ lingkungan kampus) sedangkan sisanya dijelaskan oleh sebab-sebab lain diluar model. Persamaan yang dihasilkan adalah $\mathrm{Y}=-13,084+1,277 \mathrm{X} 1+0,957 \mathrm{X} 2$ $-0,032$.

Tabel 3. Hasil Moderated Regression Analysis

\begin{tabular}{|c|c|c|c|}
\hline \multicolumn{4}{|c|}{$\begin{array}{l}\text { Lingkungan Kampus } \text { Memoderasi Pengaruh } \\
\text { Kewirausahaan Terhadap Minat Wirausaha }\end{array}$} \\
\hline \multicolumn{4}{|c|}{ Variabel Unstandardized Coefficients } \\
\hline 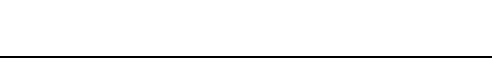 & $\mathrm{B}$ & Std. Error & \\
\hline Konstanta & $-13,084$ & 14,138 & \\
\hline $\begin{array}{l}\text { Mata kuliah kewirausahaan } \\
\text { (X1) }\end{array}$ & 1,277 & 0,510 & \\
\hline Lingkungan Kampus (X2) & 0,957 & 0,552 & \\
\hline $\begin{array}{l}\text { Mata kuliah } \\
\text { kewirausahaan* } \\
\text { Lingkungan Kampus (M) }\end{array}$ & $-0,032$ & 0,020 & \\
\hline
\end{tabular}

\begin{tabular}{lll}
\hline Variabel & $\begin{array}{l}\text { Standardized } \\
\text { Coefficients } \\
\text { Beta }\end{array}$ & Signifikansi \\
\hline Konstanta & 0,357 \\
\hline $\begin{array}{l}\text { Mata kuliah kewirausahaan } \\
\text { (X1) }\end{array}$ & 1,293 & 0,014 \\
\hline Lingkungan Kampus (X2) & 1,055 & 0,086 \\
\hline $\begin{array}{l}\text { Mata kuliah } \\
\text { kewirausahaan* }\end{array}$ & $-1,557$ & 0,108 \\
Lingkungan Kampus (M) & & \\
\hline R2: 0,260 & & \\
\hline F: 14,321 (signifikansi 0,00) & & \\
\hline sumber: olah data spss, 2017
\end{tabular}

Hasil penelitian ini tidak mendukung penelitian sebelumnya yang dilakukan oleh Sadeghi et al, (2013) yang menunjukkan bahwa kondisi lingkungan merupakan salah satu faktor utama yang dapat memperkuat atau memperlemah minat berwirausaha. Disamping itu hasil penelitian ini juga tidak sesuai dengan hasil penelitian Syarifuddin dan Iskandar (2016) yang menunjukkan bahwa semakin sering mahasiswa berada dalam lingkungan yang memberikan motivasi berwirausaha, maka semakin tinggi pula minat mahasiswa untuk berwirausaha yang dimungkinkan dapat memulai berwirausaha.

Lingkungan kampus tidak memoderasi pengaruh mata kuliah kewirausahaan terhadap minat wirausaha karena lingkungan kampus hanya memberi kesempatan bagi mahasiswa untuk mengamati dan mendalami praktek kewirausahaan namun tidak ada kewajiban untuk terlibat didalamnya, sehingga meskipun mahasiswa mengikuti mata kuliah kewirausahaan dan 
berada di lingkungan kampus berbasis entrepreneur maka belum tentu mahasiswa tersebut akan memiliki minat yang tinggi untuk berwirausaha.

Untuk menghasilkan Best Linier Unbiased Estimator (BLUE) dari penggunaan model regresi harus dilakukan evaluasi ekonometri. Tujuannya adalah untuk mengetahui apakah penggunaan model regresi sebagai alat analisis telah memenuhi persyaratan asumsi klasik. Salah satu persyaratan yang harus dipenuhi pada saat menggunakan uji moderasi (moderated regression analysis) adalah non multicolliniearity (Hair et al., 2006). Hal ini disebabkan karena munculnya variabel interaksi yang merupakan perkalian antara variabel mata kuliah kewirausahaan dan lingkungan kampus. Multikolonieritas adalah adanya suatu hubungan linier antar beberapa atau semua variabel bebas. Nilai cut off yang umum dipakai untuk menunjukkan multikolonieritas adalah nilai tolerance kurang dari 0,10 atau sama dengan nilai VIF lebih besar dari 10 (Hair et al., 2006). Hasil uji multikolonieritas dalampenelitian ini dilakukan dengan bantuan software SPSS 16,0 for windows yangditunjukkan oleh tabel berikut ini:

Tabel 4. Hasil Uji Multikolonieritas

\begin{tabular}{lll}
\hline Variabel & Tolerance & VIF \\
\hline $\begin{array}{l}\text { Mata Kuliah } \\
\text { Kewirausahaan }\end{array}$ & 0,024 & 41,107 \\
\hline $\begin{array}{l}\text { Lingkungan } \\
\text { Kampus }\end{array}$ & 0,018 & 56,960 \\
\hline Interaksi & 0,007 & 141,757 \\
\hline \multicolumn{2}{l}{ Sumber: olah data SPSS, 2017}
\end{tabular}

Sumber: olah data SPSS, 2017

Tabel 4 tersebut menunjukkan bahwa terdapat hubungan yang cukup dekat antara sesama variabel independen sehingga hasil yang diperoleh dengan menggunakan model regresi ini tidak memiliki arti karena memiliki nilai varians dan kovarians yang besar. Hal ini akan mengakibatkan prediksi sulit dilakukan. Akan tetapi penelitian ini merupakan penelitian keperilakuan sehingga munculnya multikolonieritas masihdapat diterima karena data yang diperoleh merupakan persepsi responden terhadappertanyaan kuesioner yang tidak dapat dipengaruhi oleh peneliti. Oleh karena itu peneliti melakukan post hoc yaitu menguji peran lingkungan kampus memoderasi pengaruh mata kuliah kewirausahaan terhadap minat wirausaha. Menurut Ghazali (2005), chow test adalah alat untuk menguji test for equality of coeffisients atau uji kesamaan koefisien. Variabel dikatakan memoderasi jika nilai $\mathrm{F}$ hitung $>\mathrm{F}$ tabel. Rumus persamaan chow test adalah sebagai berikut:

$$
\mathrm{F}=\frac{(\mathrm{RSSr}-\mathrm{RSSur}) / \mathrm{k}}{\mathrm{RSSur} /(\mathrm{n} 1+\mathrm{n} 2-2 \mathrm{k})}
$$

Sumber: Ghazali (2005)

RSSr : Sum of squared residual - restricted regression

RSSur: Sum of squared residual - unrestricted regression

n1, n2 : Jumlah observasi kelompok 1 dan jumlah observasi kelompok 2

$\mathrm{k} \quad$ : Jumlah parameter yang diestimasi pada unrestricted regression 
Pada penelitian ini kelompok sampel dibagi menjadi dua yaitu kelompok lingkungan kampus tinggi dan lingkungan kampus rendah. Pengelompokan tersebut dilakukan dengan mencari nilai median (split sample) dari sampel yang digunakan. Pengelompokan sampel tersebut disajikan pada tabel berikut ini:

Tabel 5. Hasil Pengelompokan Lingkungan Kampus

Runs Test

\begin{tabular}{ll}
\hline & $\begin{array}{l}\text { Lingkungan } \\
\text { Kampus }\end{array}$ \\
\hline Test Valuea & 25 \\
Cases $<$ Test Value & 49 \\
Cases $>=$ Test Value & 66 \\
Total Cases & 115 \\
Number of Runs & 69 \\
Z & 2.252 \\
Asymp. Sig. (2-tailed) & .024 \\
\hline
\end{tabular}

a. Median

Sumber: olah data SPSS, 2017

Berdasarkan pada tabel tersebut dapat diketahui bahwa nilai median untuk lingkungan kampus adalah 25 sehingga jumlah observasi lingkungan kampus tinggi sebanyak 66 orang dan lingkungan rendah sebanyak 49 orang.

Setelah dilakukan chow test maka didapatkan nilai $\mathrm{F}$ hitung yang disajikan pada tabel 6 berikut ini:

Tabel 6. Hasil Analisis Chow Test

\begin{tabular}{ll}
\hline Analisis Chow Test & Keterangan \\
\hline $\begin{array}{l}\text { Lingkungan kampus memoderasi pengaruh } \\
\text { mata kuliah kewirausahaan terhadap minat } \\
\text { wirausaha }\end{array}$ & \\
$\mathrm{F}=1117,660-(540,463+555,852) / 2$ & F hitung $<\mathrm{F}$ tabel \\
$\quad 1096,315 /(115-4)$ & \\
$=1,0805$ & \\
\hline Sumber: olah data SPSS, 2017
\end{tabular}

Berdasarkan pada tabel di atas dapat diketahui bahwa nilai $\mathrm{F}$ hitung $<\mathrm{F}$ tabel sebesar 3,08. Hal ini menunjukkan bahwa lingkungan kampus tidak memoderasi pengaruh mata kuliah kewirausahaan terhadap minat wirausaha.

Lingkungan kampus tidak memoderasi pengaruh mata kuliah kewirausahaan terhadap minat wirausaha karena di dalam lingkungan kampus mahasiswa hanya mengamati kegiatan kewirausahaan tanpa harus terlibat langsung dalam praktek kewirausahaan tersebut. 


\section{SIMPULAN}

Berdasarkan pada hasil analisis dan pembahasan dapat disimpulkan bahwa hasil analisis regresi sederhana adalah mata kuliah kewirausahaan berpengaruh secara positif dan signifikan terhadap minat wirausaha. Hasil tersebut menunjukkan bahwa semakin baik mata kuliah kewirausahaan (diukur dari maksud dan tujuan mata kuliah kewirausahaan, isi silabus dan RPS, materi, metode pembelajaran, konsep dan pemahaman mahasiswa) maka minat berwirausaha akan semakin tinggi.

Sementara itu, hasil moderated regression analysis adalah lingkungan kampus tidak memoderasi pengaruh mata kuliah kewirausahaan terhadap minat wirausaha. Hal ini menunjukkan bahwa lingkungan kampus yang berbasis kewirausahaan tidak selalu menyebabkan pengaruh mata kuliah kewirausahaan terhadap minat wirausaha menjadi lemah atau semakin kuat. Lingkungan kampus yang berbasis kewirausahaan hanya memberikan kesempatan bagi mahasiswa untuk belajar mengamati dan mendalami serta praktek kewirausahaan namun tidak ada keharusan yang mewajibkan mereka untuk terlibat didalamnya. Berbeda dengan mata kuliah kewirausahaan, mahasiswa yang mengambil mata kuliah kewirausahaan didasari oleh kesadaran sehingga mereka memiliki target, sasaran dan tujuan untuk mengembangkan potensi yang ada sehingga akan memiliki minat wirausaha yang tinggi.

\section{DAFTAR RUJUKAN}

Badan Pusat Statistik (BPS), Keadaan Ketenagakerjaan Indonesia Februari 2017, (Online : https://www.bps.go.id/index.php/brs/1376, diakses Mei 2017).

Baron, R.M. and Kenny, D.A. 1986. The Moderator-Mediator Variable Distinction in Social Psychological Research: Conceptual, Strategic, and Statistical Considerations. Journal of Personality and Social Psychology, Vol. 51 No. 6, pp. 1173-1182.

Ghozali, I. 2005. Aplikasi Analisis Multivariate dengan Program SPSS. Semarang: Badan Penerbit Universitas Diponegoro.

Ginting, M. dan Yuliawan, E. 2015. Analisis Faktor-Faktor Yang Mempengaruhi Minat Berwirausaha Mahasiswa(Studi Kasus Pasa STMIK Mikroskil Medan). Jurnal Wira Ekonomi Mikroskil. Vol.5 No. 01.Hal. 63.

Hair, J.R., Black, W.C., Babin, B.J., Anderson, R.E. and Tatham, R.L. 2006. Data Multivariate Analysis, $6^{\text {th }}$ ed. Upper Saddle River: Prentice Hall. 
Hajrah, S.B.B., dan Rahayu, W.P. 2016. Effect of Entrepreneurial Education and Economic Condition of Parents Towards an Entrepreneurship Attitudes through the Entrepreneurship Interest. Journal of Businees and Management. Vol. 18. pp. 106.

Hermina, U.N., Novieyana, S., Zain D. 2011. Pengaruh Mata Kuliah Kewirausahaan Terhadap Minat Mahasiswa Menjadi Wirausaha Pada Program Studi Administrasi Bisnis Politeknik Negeri Pontianak. Jurnal Eksos.Vol.7 No. 2.

Jogiyanto. 2005.Metodologi Penelitian Bisnis. Yogyakarta: BPFE.

Kadarsih, R., Susilaningsih dan Sumaryati, S. 2013.Faktor-Faktor Yang Mempengaruhi Minat Berwirausaha Pada Mahasiswa Program Studi Pendidikan Ekonomi FKIP UNS. Jupe UNS. Vol. 2 No. 1. Hal. 97.

Kodrat, David S. dan Christina, W. 2015. Entrepreneurship Sebuah Ilmu. Jakarta: Penerbit Erlangga.

Koranti, K. 2013. Analisis Pengaruh Faktor Eksternal dan Internal Terhadap Minat Berwirausaha. Proceeding PESAT (Psikologi, Ekonomi, Sastra, Arsitektur \& Teknik Sipil). Bandung, 8-9 Oktober 2013. Vol. 5.Hal. 5.

Lackeus, M. 2015. Entrepreneurship In Education-What, Why, When, How," European Commission.pp.11.

Lestari, R.B. dan Wijaya, T. 2012. Pengaruh Pendidikan Kewirausahaan Terhadap Minat Berwirausaha Mahasiswa di STIE MDP, STMIK MDP, dan STIE MUSI. Forum Bisnis dan Kewirausahaan. Jurnal Ilmiah STIE MDP.Hal. 118.

Moberg, K., Vestergaard, L., Fayolle, A., Redford, D., Cooney, T., Singer, S., Sailer, K. \& Filip, D. 2014.How To Asses and Evaluate The Influence of Entrepreneurship Education.A Report Of The ASTEE Project With A user Guide To The Tools. pp.12.

Naibaho, H., Adi, F., Veryco dan Sugiarto. 2010. Pengaruh Lingkungan Kampus Terhadap Motivasi Belajar Mahasiswa (Studi Kasus Universitas Harapan Surabaya). Jurnal Manajemen Pemasaran. Vol. 5 No. 1.Hal. 22.

Nurikasari, F. 2016. Pengaruh Pendidikan Kewirausahaan, Kreativitas, Dan Motivasi Berwirausaha Terhadap Minat Berwirausaha Pada Mahasiswa Pendidikan Ekonomi Universitas Kanjuruhan Malang. Fakultas Ekonomika dan Bisnis. Program Studi Pendidikan Ekonomi.

Pedoman Program Mahasiswa Wirausaha (PMW). 2015.Direktorat Jenderal Pembelajaran dan Kemahasiswaan Kementerian Riset, Teknologi, Dan Pendidikan Tinggi. 
Rahmi, E. 2015. Re-Design Mata Kuliah Kewirausahaan Sebagai Upaya Melahirkan Entrepreneur Muda. SNEMA.

Ramadhani, Nova T. dan Nurnida, I. 2017. Pengaruh Mata Kuliah Kewirausahaan Terhadap Minat Berwirausaha Mahasiswa. Journal Ecodemica. Vol.1 No. 1. Hal. 96.

Raposo, M. \& Paco, Arminda do. 2011. Entrepreneurship Education: Relationship Between Education and Entrepreneurial Activity. Psicothema. Vol. 23. pp. 454.

Rosmiati, Junias Donny T.S\& Munawar 2015. Sikap, Motivasi, dan Minat Berwirausaha Mahasiswa. JMK. Vol.17 No.1. Hal. 23.

Sadeghi, M., Mohammadi, M., Nosrati, M. \& Malekian, K. 2013.The Role of Entrepreneurial Environments in University Students Entrepreneurial Intention. Vol. 3. pp. 361.

Saiman, L. 2014. Kewirausahaan-Teori, Praktik, dan Kasus-kasus. Jakarta: Penerbit Salemba Empat.

Stewart, W.H., Watson, W.E., Carland, J.C. \& Carland, J.W. 1998.A Proclivity For Entrepreneurship: A Comparison Of Entrepreneurs, Small Business Owners, and Corporate Managers. Journal of Business Venturing. pp. 189-214.

Sugiyono. 2016. Metode Penelitian Manajemen. Bandung: Penerbit Alfabeta.

Suryana. 2003. Kewirausahaan. Jakarta: Penerbit Salemba Empat.

Suryana. 2010. Metodologi Penelitian. Buku Ajar Perkuliahan: Universitas Pendidikan Indonesia.

Susilaningsih. 2015. Pendidikan Kewirausahaan Di Perguruan Tinggi: Pentingkah Untuk Semua Profesi?. FKIP Universitas Sebelas Maret Surakarta.

Syarifuddin, D. dan Iskandar, I. 2016. Dampak Lingkungan Terhadap Minat Mahasiswa Berwirausaha (Studi Kasus pada Mahasiswa STP ARS Internasional Bandung).Working Paper.Hal. 12.

Wibowo, M. 2011. Pembelajaran Kewirausahaan dan Minat Wirausaha Lulusan SMK. Eksplanasi. Vol. 6.Hal. 113-114.

Wiyadi, H. dan Rochmania, D.D. 2016. Pengaruh Mata Kuliah Kewirausahaan dan Motivasi Diri Terhadap Minat Berwirausaha Mahasiswa Unhasy Jombang. Discovery, Vol.1 No. 2.Hal.35. 
